\title{
Shallow-water scleractinian corals of Ascension Island, Central South Atlantic
}

\author{
HELMUT ZIBROWIUS ${ }^{1}$, PETER WIRTZ ${ }^{2}$, FLAVIA L.D. NUNES ${ }^{3}$, BERT W. HOEKSEMA ${ }^{4}$ \\ AND FRANCESCA BENZONI ${ }^{5}$ \\ ${ }^{1}$ Le Corbusier 644, 280 Boulevard Michelet, 13008 Marseille, France, ${ }^{2}$ Centro de Ciências do Mar, Universidade do Algarve, \\ P-8000-117 Faro, Portugal, ${ }^{3}$ Institut Universitaire Européen de la Mer, Université de Bretagne Occidentale, Technopole Brest-Iroise, \\ 29280 Plouzané, France, ${ }^{4}$ Department of Marine Zoology, Naturalis Biodiversity Center, P.O. Box 9517, 2300 RA Leiden, the \\ Netherlands, ${ }^{5}$ Department of Biotechnology and Biosciences, University of Milano-Bicocca, Piazza della Scienza 2, 20126 Milano, \\ Italy
}

The presence of five shallow-water scleractinian species at Ascension Island is confirmed, i.e. Favia gravida, Madracis sp., Siderastrea radians, Polycyathus atlanticus and Rhizosmilia gerdae. The three former are zooxanthellate, the two latter azooxanthellate. A sixth species, Cladocora debilis (azooxanthellate), dredged from moderately deep water is also expected to occur in shallow water. Madracis $s p$. and $\mathrm{P}$. atlanticus are new records for the island. A previous record of Astrangia solitaria at Ascension is now referred to as P. atlanticus. Favia gravida, S. radians and C. debilis are amphi-Atlantic. Rhizosmilia gerdae is currently known only from Ascension Island and the Western Atlantic. None of the species are endemic to Ascension Island. No member of the family Dendrophylliidae has as yet been found at Ascension, whereas that family is represented at its nearest neighbour, St Helena Island.

Keywords: Cnidaria, Scleractinia, St Helena, Atlantic islands, Cryptochiridae

Submitted 16 December 2013; accepted 3 September 2014; first published online 3 November 2014

\section{INTRDDUCTION}

Ascension Island $\left(7^{\circ} 57^{\prime} \mathrm{S} 14^{\circ} 22^{\prime} \mathrm{W}\right)$ is one of the most remote islands in the Atlantic, being located $\sim 1300 \mathrm{~km}$ from St Helena (the nearest island), $\sim 2300 \mathrm{~km}$ from Recife (Brazil) and $\sim 1500 \mathrm{~km}$ from Cape Palmas (Liberia). Accordingly, the island has been less visited by expeditions or individual naturalists than most other Atlantic islands or archipelagos and for a long time the description of the island's biological diversity remained relatively incomplete. A representative list of the older visiting expeditions and corresponding literature can be found in Manning \& Chace (1990). The onset of main collecting efforts is quite recent, made possible when Ascension became more easily accessible as an important military and space communication base. This finally resulted in some monographic work on major zoological groups such as molluscs (Rosewater, 1975), echinoderms (Pawson, 1978), fishes (Lubbock, 1980) and decapod crustaceans (Manning \& Chace, 1990).

Shallow-water scleractinian corals have occasionally been observed, collected and reported on in the literature (see historical account below) but have not yet been the subject of a more comprehensive approach. A recent expedition (2012) to Ascension has permitted a reassessment of its shallowwater coral fauna by in situ photography and sampling. The newly obtained data are now combined with information collected from the literature and from investigating museum

Corresponding author:

P. Wirtz

Email: peterwirtz2004@yahoo.com collections. The present study also sheds light on the true identity of some of the corals mentioned in previous reports, which had remained uncertain or enigmatic.

\section{MATERIALS AND METHODS}

In August/September 2012, coral specimens were photographed in situ and collected by one of us (P.W.) from tide pools and by scuba diving in a depth range of $0-25 \mathrm{~m}$. Exact sampling locations are listed in the species sections. Dry samples and samples in ethanol were deposited in the coral collection of Naturalis Biodiversity Center, Leiden, the Netherlands (RMNH Coel. 40158-40172, 41529, 41542).

DNA was extracted from specimens stored in ethanol using the DNEasy Blood and Tissue kit (Qiagen). Amplification of three loci was attempted to assist in species identification, including two nuclear genes, $\beta$-tubulin and Pax- $\mathrm{C}$ intron, and one mitochondrial gene, cytochrome oxidase I (COI). PCR amplification and sequencing were performed according to published protocols (Kitahara et al., 2010; Nunes et al., 2011). DNA sequences were compared against the NCBI's BLAST database (http://blast.ncbi.nlm.nih.gov/Blast.cgi). Sequences have been deposited in GenBank with accession number KM391402 for Favia gravida specimen RMNH Coel. 40166 and KM391399-KM391401 for three markers of Siderastrea radians specimen RMNH Coel. 40163. Sequences for COI were also obtained for S. radians specimens Coel. 40164 and 40165 , but because they were identical to specimen RMNH Coel. 40163, only one sequence was submitted to GenBank. 
Searching the literature and museum collections provided many additional, earlier and widely dispersed data on the shallow-water scleractinian fauna of Ascension Island. The following abbreviations stand for the institutions mentioned:

BMNH: The Natural History Museum, London; formerly British Museum (Natural History).

NCBI: National Center for Biotechnology Information, Bethesda, MD.

RMNH: RMNH collection of Naturalis Biodiversity Center, Leiden; formerly Rijksmuseum van Natuurlijke Historie.

USNM: National Museum of Natural History, Smithsonian Institution, Washington, DC.

ZMA: ZMA collection of Naturalis Biodiversity Center, Leiden; formerly Zoölogisch Museum, Amsterdam.

\section{HISTORICAL ACCDUNT OF CORAL RECDRDSATASCENSION}

This historical account is not limited to strictly 'shallow-water' corals. The very first recognizable and precisely described scleractinians from Ascension were dredged from deep water.

It is uncertain if Cunninghame's (1699) 'Corallium album minus Conglomeratum' from Ascension should be interpreted as a scleractinian. The characterization is too vague, as already stated by Ridley (1881). The first precise records of deep-water scleractinians from Ascension are two species from the 'Challenger' expedition in 1876 (Moseley, 1881): Caryophyllia laevicostata Moseley, 1881 (junior synonym of C. atlantica (Duncan, 1873)) and Solenosmilia variabilis Duncan, 1873 (BMNH; samples re-examined by Zibrowius, 1980). In the same year, Ridley (1881) was the first to report a shallow-water scleractinian which he named Platygyra ascensionis (a junior synonym of Favia gravida Verrill, 1868; see Hoeksema \& Wirtz, 2013). The coral in question was collected by T. Conry, surgeon on the island and an active naturalist collecting for the BMNH.

Studer (1889) included Ridley's Platygyra ascensionis in his inventory of marine species from Ascension. He did not provide any new record of scleractinians from shore collecting or the few trawls done by the 'Gazelle' when visiting the island in 1874 during a circumnavigation. On the way back from Antarctica, in 1904, the 'Scotia' dredged material of Cladocora debilis at Ascension $(73 \mathrm{~m})$. Not included in Gardiner's (1913) report on the corals from the expedition, this sample $(\mathrm{BMNH})$ was first mentioned by Zibrowius (1980).

A collection by the Ascension diving club of the British base, made in 1971/1972 and subsequently sent to the $\mathrm{BMNH}$, includes the scleractinians Favia gravida and Siderastrea radians.

Studying shrimps collected by the Ascension diving club of the British military base and by Smithsonian scientists (including R.B. Manning) in 1971, Chace \& Manning (1972) mentioned Favia living in a 'coral pool'. Again using material collected by the Ascension diving club (above) and Smithsonian scientists in 1971 and 1976 (above), Kropp \& Manning (1987) reported cryptochirid crabs from Ascension, one of them from Favia.

Reporting results of a 1976 inshore benthic survey, Price \& John (1980) note that 'reef building corals are entirely absent around Ascension', but that inland pools are 'lined with coral growths'. Favia sp. can thus be seen in their figure $11 \mathrm{~b}$, although this photograph is not clear.

On the way to St Helena, in 1983, Den Hartog (1989a) collected Favia gravida from an inland marine pool (RMNH collection of Naturalis Biodiversity Center, Leiden; Hoeksema, 2012). When investigating for stygobionts at Ascension in 1989, Stock \& Vonk (1989) noticed Favia in pools. Their specimens are in the ZMA collection of Naturalis Biodiversity Center, Leiden (Hoeksema, 2012).

Irving (1989) described sublittoral communities of Ascension Island, based on dives in 1985 down to a depth of $45 \mathrm{~m}$, and mentioned the presence of Astrangia, Madracis and Siderastrea (no species names were given). He later (Irving, 2013) called these species Astrangia solitaria, Madracis decactis and Siderastrea radians, and added a fourth species, Rhizosmilia gerdae; reference samples were deposited at USNM and, according to Werner (1997), also at $\mathrm{BMNH}$

Finally, Werner's (1997) Master's thesis was based on museum specimens (various collectors, including some of the above-mentioned) of the scleractinian corals Madracis decactis, Favia gravida and Siderastrea radians from Ascension and St Helena Islands.

\section{RESULTS}

Cladocora debilis Milne Edwards \& Haime, 1849

Family incertae sedis; currently not assigned to a known family.

Cladocora debilis: Zibrowius, 1980, p. 31, Plate $11 \mathrm{~A}-\mathrm{L}$; Cairns, 2000, pp. 88-92, Figure 18, $102-107$.

Material (old): Ascension, off Pyramid Point, $7^{\circ} 36^{\prime} \mathrm{S}$ $14^{\circ} 33^{\prime} \mathrm{W}, 73 \mathrm{~m}$, 'Scotia', no station number, 9.6.1904, one branch, BMNH 1929.10.22.36.

Habitat: This old dredge record from moderately deep water is included here because the species can be expected to occur also in shallow water: at Madeira Island, it was found in a dark cave in $7 \mathrm{~m}$ depth by P.W. Cladocora debilis is azooxanthellate and ranges into deeper water than the Mediterranean C. caespitosa (Linnaeus, 1767) and the West Indian C. arbuscula (Lesueur, 1821), which are both typical zooxanthellate shallow-water species.

Morphology: For detailed descriptions of C. debilis with comments on synonymy and distribution see Zibrowius (1980) and Cairns (2000). The corallum is typically composed of thin slender corallites (generally only about $3 \mathrm{~mm}$ in diameter) from which secondary corallites branch at right angle, and occasionally tertiary corallites from the secondary ones. Colonies attached to hard ground are more bushy. Discrete paliform lobes form a single palar crown.

The single record from Ascension (together with another one from St Helena) had first been reported by Zibrowius (1980). The species had been described as Cladocora debilis Milne Edwards \& Haime, 1849, from Madeira; C. patriarca Pourtalès, 1874, from Brazil; and C. paulmayeri Döderlein, 1913, from the western Mediterranean. Each of these names has also been used for populations in other areas. Cladocora debilis is known from the western Mediterranean and various areas in the eastern and western Atlantic: Azores (new record: RMNH Coel. 16340-16356), Madeira (RMNH Coel. 12547-12550), Canary Islands (RMNH Coel. 12614$12717,16338,16337,16357$ ), Cape Verde Islands (RMNH 
Coel. 16337), West Africa from southern Morocco to Gabon, western Atlantic from Florida to Colombia and Brazil through Saint Paul's Rocks in the equatorial Atlantic, Ascension and St Helena.

\section{Family Dendrophylliidae}

No species of the conspicuous, well-defined scleractinian family Dendrophylliidae has yet been reported from Ascension Island, whereas a shallow-water dendrophylliid, Balanophyllia helenae Duncan, 1876, is endemic and common at St Helena and well documented by samples deposited in museum collections (BMNH, RMNH Coel. 18002, 18008, etc.; Den Hartog, 1989b). However, Irving's (2013) presentation of Ascension corals contains an intriguing illustration (figure 16.4) of two dendrophylliid colonies. Its legend is: 'The star fish Linckia guildingii with the brown coral Astrangia solitaria'. To the right of the star fish is a large brownish dendroid dendrophylliid colony, maybe $10 \mathrm{~cm}$ high or more (there is no scale), with many calices on at least two main stems. Further, next to the starfish, between two arms, is another, low, yellow-orange dendrophylliid colony, comprising at least three clustered calices. There is no trace of any other scleractinian in this photo, in particular none the aspect of which could suggest Astrangia solitaria (Lesueur, 1817).

Coral samples collected at Ascension in 1985 have been deposited by R. Irving at the Smithsonian Institution (acquisition number 373870 ) and are registered there under USMN numbers with preliminary identifications made by S.D. Cairns in 1987. These include specimens labelled Astrangia sp. (USNM 78388-78390 - herein referred to as Polycyathus atlanticus, see the account of that species below) but no dendrophylliid species.

The larger brown dendrophylliid in Irving's figure 16.4 may suggest a species of Tubastraea, similar in colony shape and arrangement of lateral calices on the main stem to Tubastraea sp. of the Cape Verde Islands (already known from the 'Challenger' expedition but not yet adequately described and identified) or to the Indo-Pacific T. micranthus (Ehrenberg, 1834). As for the other, small dendrophylliid of figure 16.4, it might be a young colony in a different colour morph of the same species (some dendrophylliids do occur in different colours), or a different species. However, all this is speculation in the absence of collected samples.

The starfish in Irving's figure 16.4, called 'Linckia guildingii', is another problem. It does not resemble L. guildingi, well known to P.W. from the tropical eastern Atlantic. The photo was therefore sent to the starfish expert Christopher Mah, who wrote 'Looks like either Linckia multifora or possibly Linckia columbiae', suggesting that the photo was in fact taken in 'the tropical Indo-Pacific to the East Pacific' (C. Mah in litt. to P.W.). Robert Irving has extensively worked at the Pitcairn Islands, Polynesia. Because of the identity of the starfish in his figure 16.4, and because of the dendrophylliid corals near it (Tubastraea?), we suspect that the photo printed as figure 16.4 actually was taken in the Indo-Pacific and not at Ascension Island. Thus we conclude that the photo in question has slipped into Irving's (2013) Ascension paper by mistake and shows marine life photographed somewhere else. Of course, we cannot exclude the possibility that dendrophylliids do exist at Ascension Island but this has yet to be shown.
Favia gravida Verrill, 1868

Family Faviidae

Favia gravida Verrill, 1868, pp. 354-355; Laborel, 1971, pp. 191-195, plate IV 1-6; Laborel, 1974, p. 431.

Favia conferta Verrill, 1868, p. 355.

Platygyra ascensionis Ridley, 1881, pp. 438-440, Figures $1 \& 2$.

Favia: Chace \& Manning, 1972, p. 3.

Favia sp.: Price \& John, 1980, p. 263, figure 11b.

Material (2012, P.W.): Ascension, tidal pool, Shelly Beach (o7 ${ }^{\circ} 59.510^{\prime} \mathrm{S} 14^{\circ} 23.695^{\prime} \mathrm{W}$ ), 7 September 2012, four specimens in ethanol (RMNH Coel. 40166). Older samples: Ascension, locality not specified, coll. T. Conry, one small beach-worn colony (BMNH 1881.10.10.1), the true holotype of Platygyra ascensionis Ridley, 1881. - Ascension, locality not specified, one colony mistakenly labelled 'Coeloria (Platygyra) ascensionis Ridley, Holotype' [this specimen has no type status but is in fact another, much larger, specimen collected by T. Conry; see discussion below] (BMNH 1884.4.29.1). - Ascension, locality not specified, one hemispheric colony with cryptochirid crypt, labelled 'Platygyra ascensionis' (BMNH 1925.3.23.1) [originally probably part of lot $1884.4 .29 .1-2$, collector T. Conry]. - Ascension, Southwest Bay, $3 \mathrm{~m}$, coll. Ascension diving club, three colonies with cryptochirid crypts (BMNH 1980.9.19.1-3). - Ascension, locality not specified, coll. Ascension diving club, one colony with cryptochirid crypts (BMNH 1980.9.19.4). - Ascension, inland tide pool, [i.e. Southwest Bay], coll. Ascension diving club, one colony (BMNH 1980.9.19.5). - Ascension, Northeast Bay, tide pools on rocky point W of Main Beach, coll. R.B. Manning, 19.5.1971 (Asc 18), one colony with cryptochirid crypts (USNM). - Ascension, Shelly Beach, tide pools in flat exposed at lower tide on open beach, coll. R.B. Manning, 23.5.1971 (Asc 23), two colonies with cryptochirid crypts (USNM). - Ascension, Shelly Beach, inland tide pool, coll. R.B. Manning, 23.5.1971 (Asc 19), 60 colonies and fragments (USNM). - Ascension, Southwest Bay, northern edge, Turtle Shell Beach, tide pool, coll. R.B. Manning, 25.5.1971 (Asc 23), four colonies with cryptochirid crypts (USNM). - Ascension, Mac Arthur Point, intertidal rocks, coll. R.B. Manning et al., 13.7.1976, one colony with cryptochirid crypts (USNM). Ascension, Shelly Beach, inland tide pool, coll. R.B. Manning et al., 13.7.1976, $\sim 35$ colonies and fragments

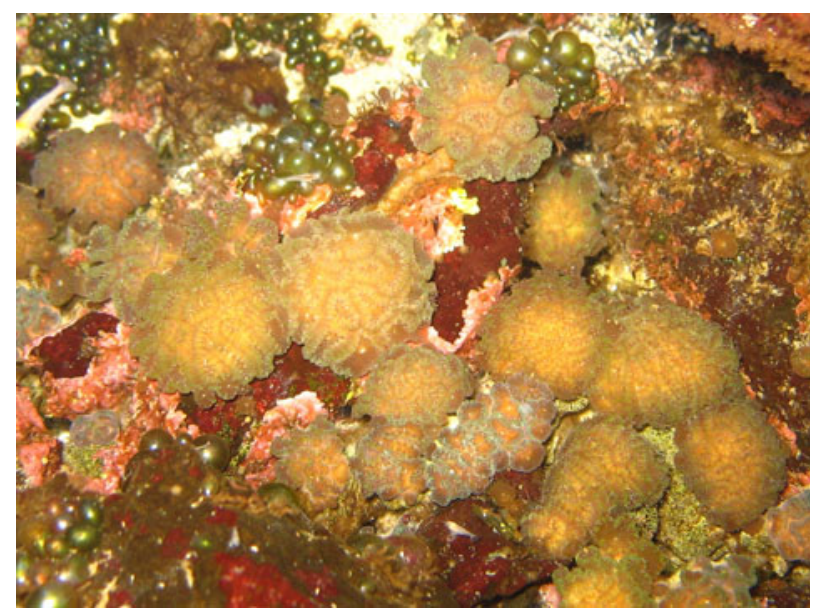

Fig. 1. Live coral of Favia gravida specimen in tidal pool at Shelly Beach (photo P.W.). 
(USNM). - Ascension, Mars Bay, exposed rocky shore with tide pools, coll. J.C. den Hartog, 31.5.1983 (stat. 1), seven colonies with cryptochirid crypts (RMNH Coel. 17341). Ascension, Shelly Beach, inland tide pool, coll. J.C. den Hartog, 1.6.1983 (stat. 2), 16 colonies (RMNH Coel. 17339). - Ascension, Shelly Beach, easternmost anchihaline coral pool, J.H. Stock 2.11.1989 (89-906), many colonies (ZMA Coel. 8467). - Ascension, same locality as before, J.H. Stock 10.11.1989 (89-933), two colonies (RMNH Coel. 23341), many colonies (ZMA Coel. 8466).

Habitat: Free-living colonies in shallow, tidal, inland rock pools, which are in subterranean connection with the nearby ocean (Chace \& Manning, 1972; Price \& John, 1980; Hoeksema, 2012, 2013; Hoeksema \& Wirtz, 2013). The population in this sheltered environment shows modifications that appear to be related to their special environmental conditions, such as calm water and warming (because of reduced water exchange). Many previous records of the species from Ascension Island concern this easily accessible population in pools (shallow, predominantly free-living; Figure 1).The species also occurs in the normal, attached mode of life as patchy colonies in the open sea, from about high water mark down to at least $5 \mathrm{~m}$ depth. In the sublittoral, the attached form of this species is much less common than Siderastrea radians. The occurrence of Favia at Ascension Island has repeatedly been mentioned in ecological and carcinological studies (Chace \& Manning, 1972; Price \& John, 1980; Kropp \& Manning, 1987; Stock \& Vonk, 1989; Manning \& Chace, 1990).

Morphology (see also Hoeksema, 2012, 2013): Colonies attached or free-living. Calices $\sim 0.5 \mathrm{~cm}$ in length; less elongate than in specimens from Brazil (Amaral \& Ramos, 2007).

Favia gravida had originally been described by Verrill (1868) from the Abrolhos Archipelago, Bahia State, Brazil and Verrill's Favia conferta, also from Brazil, is considered synonymous. Modern authors were interested in the diversity of morphotypes found in Brazil (Laborel, 1971; Amaral \& Ramos, 2007).

Platygyra ascensionis was described by Ridley (1881) from Ascension on the basis of a single, small, beach-worn colony, collector T. Conry (BMNH 1881.10.10.1; Figure 2A, B). Ridley mistakenly considered this specimen as a 'portion of what was probably a globose colony', in fact it is a flat, complete, colony as evident when examining its lower side showing a detachment scar (Figure 2B). Matthai (1928, p. 278) was correct when referring Ridley's $P$. ascensionis to the genus Favia: 'judging from the three co-types in the British Museum, it is related to Favia fragum'. However, he was wrong in considering three colonies as 'co-types' of Ridley's species, since Ridley's description was based on a single colony (the holotype characterized above). The two other specimens from the same collector ( $\mathrm{T}$. Conry) referred to by Matthai were received later (BMNH 1884.4.29.1-2) and, not being included in Ridley's description, cannot be co-types. In 1975 these specimens could not be found under the $1884 \ldots \ldots$ number, but it appears that $\mathrm{BMNH}$ 1925.3.23.1 could be one of them, accidentally re-registered under a new number. Another of these old specimens was available for loan to B.W.H. in 2013 under the old BMNH number 1884.4.29.1 (Figure $2 \mathrm{C}$ ).

Studying most diverse Favia populations from Brazil, Laborel (1971) pointed out the wide morphological plasticity of F. gravida. When subsequently he investigated Favia populations from the Gulf of Guinea, he referred these to the same species (Laborel, 1974). He finally had the opportunity to see series of samples from both St Helena and Ascension (especially those collected by Smithsonian scientists in 1971 and 1976). This confirmed his view of an amphi-Atlantic species, very variable in calice shape and size, passing from asteroid to meandroid, these various aspects depending, in his understanding (discussions with H.Z.), on environmental factors combined with genetics.

Favia fragum (Esper, 1788) is a quite distinct species, e.g. its calices commonly are less elongate (compare Roos, 1971; Hoeksema et al., 2012; see considerations in Laborel, 1971, 1974). Molecular evidence also supports their status as two distinct species (Nunes et al., 2008, 2011).

Favia gravida occurs in the Atlantic from the coast of Brazil and islands off Brazil (Atol das Rocas, Fernando d Noronha, Abrolhos, Trindade) through the mid-oceanic islands of Ascension and St Helena to the Gulf of Guinea (the islands; the coast of Gabon) (see map in Hoeksema, 2012). This distribution does not overlap with that of Favia fragum, the other amphi-Atlantic species, known from the Caribbean and the Cape Verde Islands (Hoeksema et al., 2012).

At Ascension, F. gravida colonies are frequently inhabited by a cryptochirid crab, Troglocarcinus corallicola Verrill, 1908 (see Kropp \& Manning, 1987). The deep crypts of the crab, with a lunuliform orifice, are present in many colonies from various localities on the open rocky coast, rock pools included. However, no crypts have been found on the abundant material from the population in the inland pools at Shelly Beach, in contrast to the information by Kropp \& Manning (1987).

\section{Madracis sp}

Family Pocilloporidae

Madracis: Irving, 1989, p. 74.

Madracis decactis: Werner, 1997, pp. 18-21(-26); Irving, 2013, p. 217, 218, figure 16.3 .

Material (2012, P.W.): Ascension, English Bay (07 $53.653^{\prime} \mathrm{S}$ $\left.14^{\circ} 22.950^{\prime} \mathrm{W}\right), 11 \mathrm{~m}$ depth, 4 September 2012 , one dry specimen (RMNH Coel. 40158); 30 August 2012, seven specimens in ethanol (RMNH Coel. 40160). - Comfortless Cove (07 ${ }^{\circ} 54.614^{\prime} \mathrm{S} 14^{\circ} 24.212^{\prime} \mathrm{W}$ ), 29 August 2012, seven specimens in ethanol (RMNH Coel. 40161). - Boatswain Bird Island $\left(07^{\circ} 56.182^{\prime} \mathrm{S} 14^{\circ} 18.516^{\prime} \mathrm{W}\right), 1$ September 2012 , one specimen in ethanol (RMNH Coel. 40162).

Older samples: Two samples from Ascension collected in 1985 and donated by Robert Irving are registered Madracis decactis, USNM 78224, USNM 78394. Both were examined on the basis of photos.

Habitat: A common species on shaded vertical and overhanging walls, from 3 to at least $15 \mathrm{~m}$ depth; there are several colour morphs, ranging from brilliant green to brown and blue (Figures $3 \& 4$ ).

Morphology: Colonies attached, predominantly encrusting with a tendency to form knobs. Calices $1.8-2.0 \mathrm{~mm}$ in maximum diameter, circular to polygonal in outline. Ten septa reach the columella and fuse with it. A second cycle of septa is generally absent though some corallites may show initial formation of rudimentary secondary septa (Figure $5 \mathrm{G}$ ). The upper edge of the septa is lower than the peripheral corallite edge (Figure $5 \mathrm{D}-\mathrm{F}$ ). Coenosteum absent (Figure $5 \mathrm{~A}-\mathrm{C}$ ). While RMNH Coel 40160 shows a rather regular, circular corallite outline and radially arranged septa 

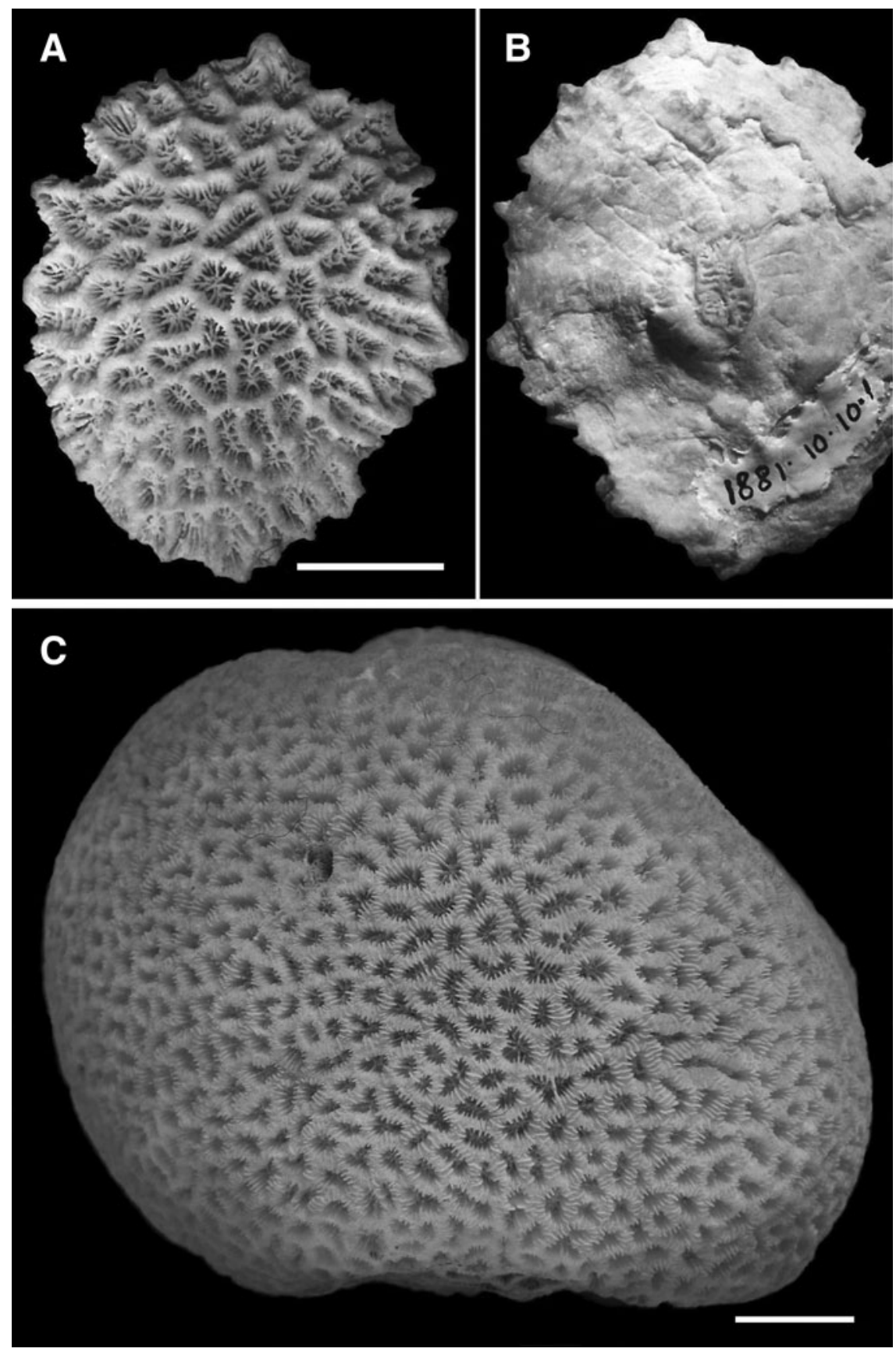

Fig. 2. Holotype of Platygyra ascensionis from Ascension Island (BMNH 1881.10.10.1; photo H.Z.): (A) upper side showing eroded calices, (B) lower side showing detachment scar indicating that the specimen was free-living. (C) Favia gravida skeleton from Ascension, labelled 'Coeloria (Platygyra) ascensionis' (BMNH 1884.4.29.1). Scale bars: $1 \mathrm{~cm}$ (photo B.W.H.).

(Figure $5 \mathrm{~A}, \mathrm{D}, \mathrm{G})$, RMNH Coel 40162 (Figure $5 \mathrm{~B}, \mathrm{E}, \mathrm{H}$ ) and, even more so, RMNH Coel 40161 (Figure $5 \mathrm{C}, \mathrm{F}, \mathrm{I}$ ) have irregularly shaped corallites and columella.

The species identity of the encrusting Madracis from Ascension (growing into large colonies and showing various colour morphs) remains problematic. It was mentioned by Irving (1989) as Madracis and later (Irving, 2013) as M. decactis. Part of Irving's samples is deposited at USNM and detailed photos were available to us: this is the same species as observed and collected in 2013 (P.W.). Werner (1979) had seen only one sample (USNM 78224) and part of his description of (presumed) 'Madracis decactis' appears to be based on it.
Lyman's (1859) original description of Madracis decactis (then Astraea decactis) is open to interpretation since it was not illustrated. Type material (presumed to be from Florida) does not seem to exist any longer. Information that can be deduced from Lyman's text: colony forming an irregular crust; endothecal dissepiments to be seen on cross sections; 10 exsert septa; columella compressed and styliform; calice surrounded by a line of 'grains' defining a 'more or less regular hexagon'. There is no information on the extent of coenosteum, other than the enigmatic expression that calices are 'nearly circular when not crowded'.

The partly obscure description by Lyman (1859), the absence of illustrations and the loss of the type material has 

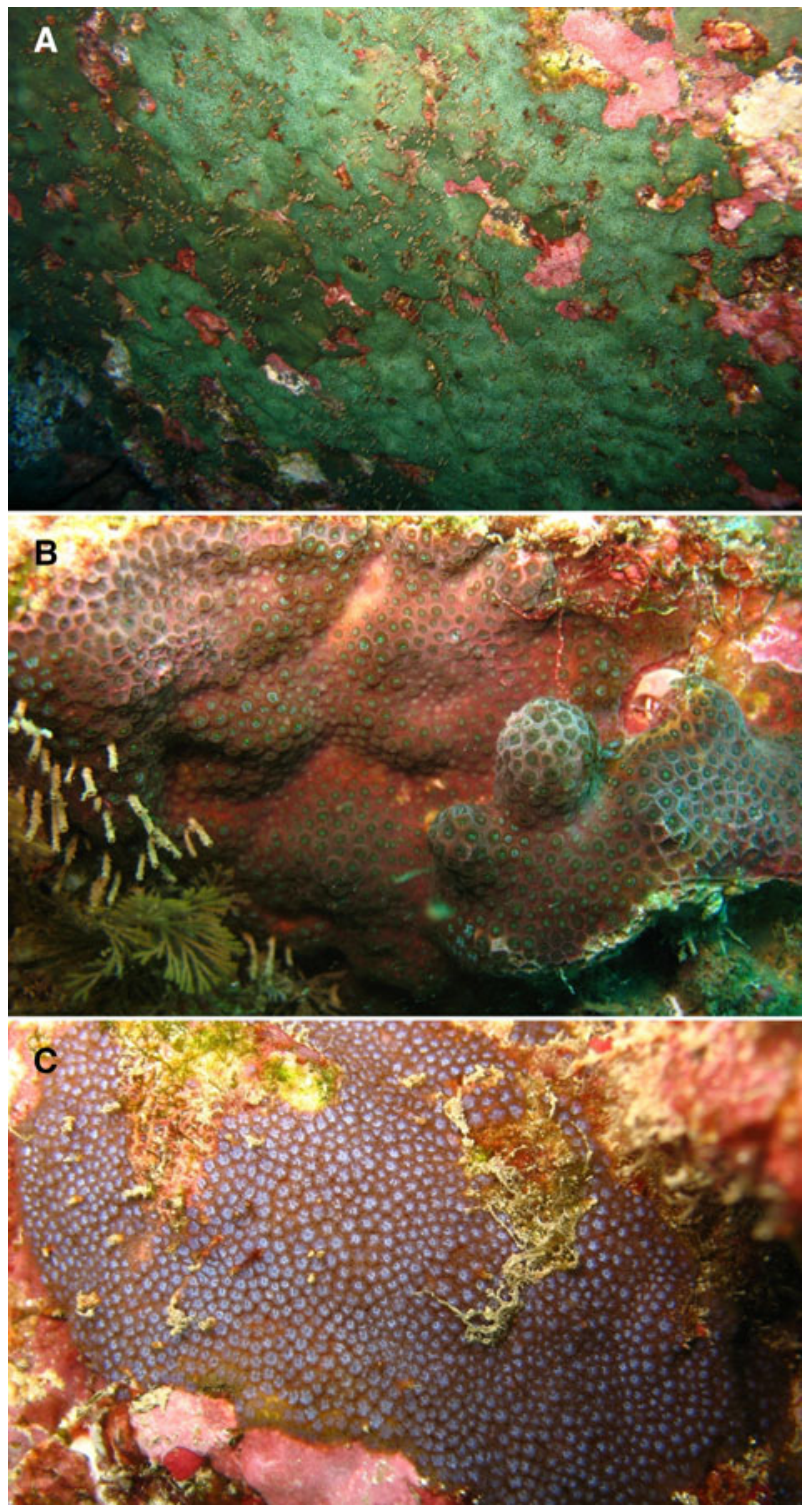

Fig. 3. Three live colonies of Madracis sp. showing encrusting growth form and different colour morphs (A-C), all from English Bay (photos P.W.).

led to Lyman's species name being used for Madracis populations from all over the tropical Atlantic, including Brazil (Laborel, 1971), the Gulf of Guinea (Laborel, 1974), Ascension and St Helena (Werner, 1997) and even the Indo-Pacific (Veron, 2000). All this needs to be revisited critically. Should the form illustrated by Roos (1971: Pl. VIIa-b), from Curaçao, represent the true $M$. decactis (it in fact seems to correspond to the presently prevailing understanding of Lyman's species) then the Madracis from Ascension is a different species. In the current acceptance, $M$. decactis is characterized by corallites that are typically separated by a (narrow) spinulated coenosteum area above which the usually 10 thick (rarely eight or nine) septa are projecting (Zlatarski \& Estalella, 1982; illustrations in NMiTA, 2013).

The absence of an extended coenosteum between the calices also characterizes Madracis pharensis (Heller, 1868), a species occurring all over the Mediterranean (type locality is in the Adriatic) and widely throughout the Atlantic (present also at St Helena but not yet observed at

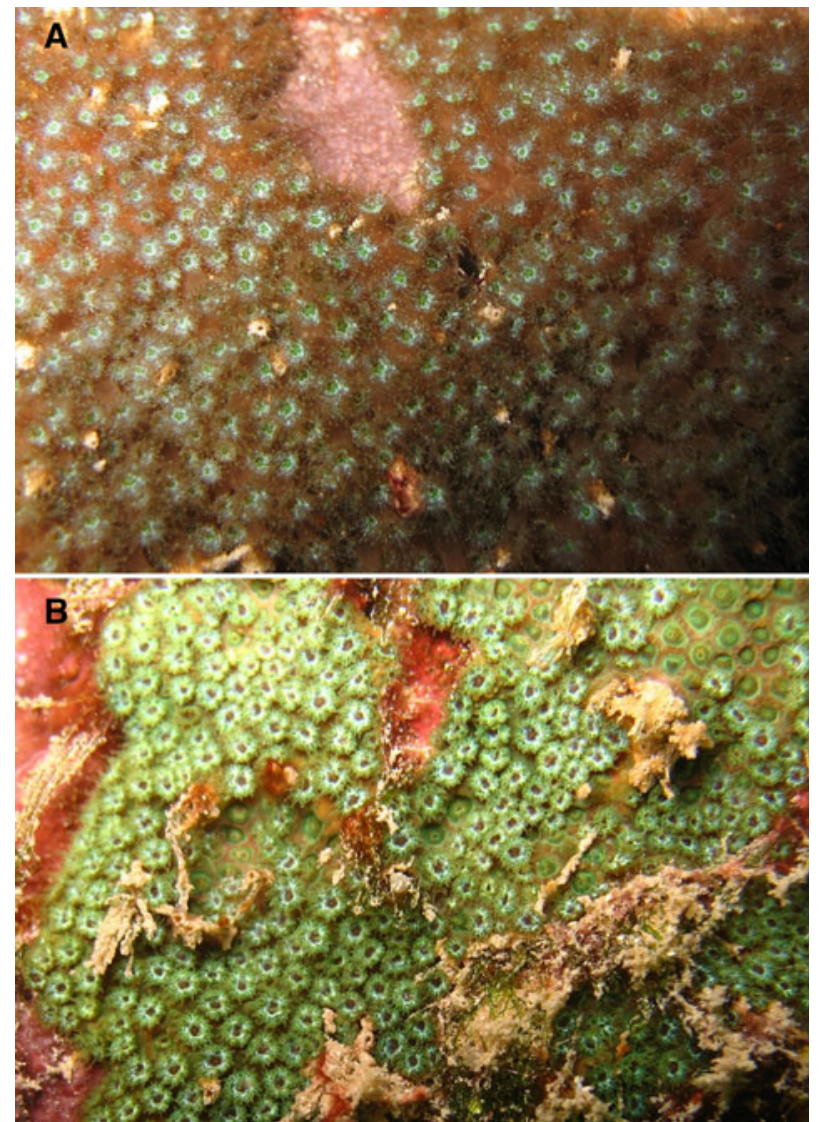

Fig. 4. Brown (A) and green (B) variety of Madracis sp. showing expanded polyps, English Bay (photos P.W.).

Ascension). In M. pharensis (see Zibrowius, 1980 for the description of Mediterranean colonies) corallites are closely packed, not separated by coenosteum and the septa lie below the edge of the common corallite wall. However, its secondary septa are generally well developed, though shorter than the primaries.

On the basis of these considerations, for the time being, we prefer not to assign Madracis sp. from Ascension (the same species also occurs at St Helena) to any of the known Madracis species.

Molecular studies will probably help to understand the phylogenetic relationship between Madracis sp. from Ascension and its congeners all over the Atlantic; some of these species have even already been analysed from a genetic point of view (Diekmann et al., 2001; Frade et al., 2010).

Polycyathus atlanticus Duncan, 1876

Family Caryophylliidae (but needs revision)

Polycyathus atlanticus Duncan, 1876, p. 433, pl. 38, Figures 14-16.

Agelecyathus helenae Duncan, 1876, p. 434, pl. 39, Figures 4-6.

Agelecyathus helenae var. minor Duncan, 1876, p. 434.

Material (2012, P.W.): Ascension, Panam Bay (07 $53.654^{\prime} \mathrm{S}$ $\left.14^{\circ} 23.676^{\prime} \mathrm{W}\right), 6$ September 2012, two specimens in ethanol (RMNH Coel. 40168), three specimens in ethanol (RMNH Coel. 40169). - Ascension, Wigan Pier (07 $53.638^{\prime} \mathrm{S}$ $\left.14^{\circ} 23.010^{\prime} \mathrm{W}\right), 7$ September 2012, three dry specimens (RMNH Coel. 40170). - Ascension, English Bay (07 ${ }^{\circ} 53.653^{\prime} \mathrm{S}$ $14^{\circ} 22.950^{\prime} \mathrm{W}$ ), 4 September 2012, one dry specimen (RMNH 

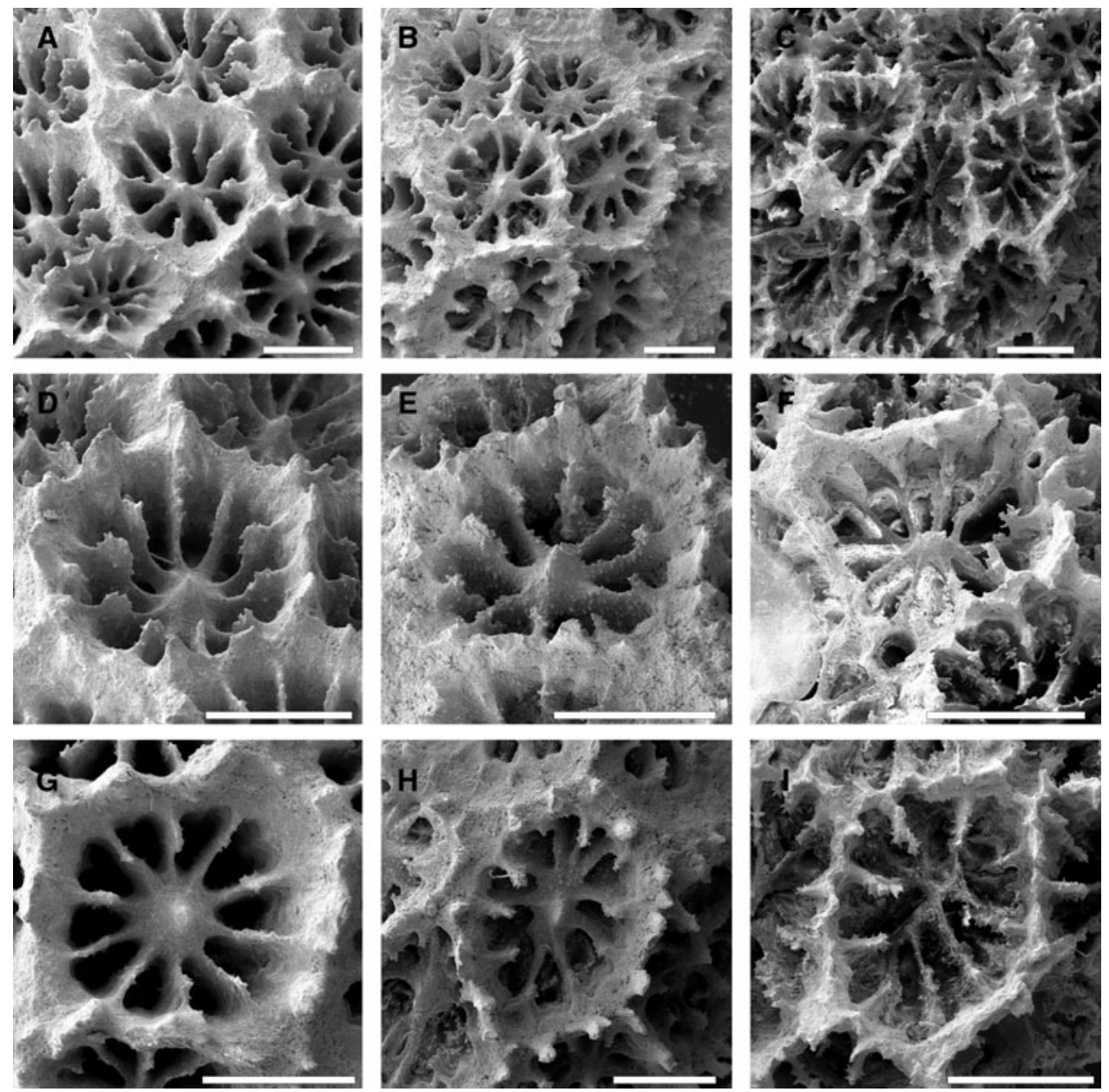

Fig. 5. Overviews and close-ups of calices of three specimens of Madracis sp. from Ascension Island showing calicular and septal arrangements: (A, D, G) RMNH Coel. 4016o, (B, E, H) RMNH Coel. 40162, (C, F, I) RMNH Coel. 40161. Note that calices are directly adjacent to each other without a coenosteum in between them. Scale bars: $1 \mathrm{~mm}$ (photos F.B.).

Coel. 41529). Older samples: Four samples from Ascension collected in 1985 and donated by Robert Irving are registered as Astrangia sp., USNM $78388-78391$. Three of these (USNM $78388,78389,78390)$ were examined on the basis of photos.

Habitat: Moderately common below large boulders in at least $10-15 \mathrm{~m}$ depth.

Morphology: Small colonies, with rather low subcylindrical corallites on continuous common coenosteum (Figure 6A). Calice inside more or less brownish; four cycles of septa, the fourth often incomplete (Figure 6A-C). More or less rod-like pali, or septal edges more denticulate, low central papillose area without really distinct columella (Figure 6C).
More extended colonies covering larger surfaces can be expected (by analogy with unpublished observations made by H.Z. on St Helena material), but have not been collected at Ascension Island.

Polycyathus atlanticus Duncan, 1876, Agelecyathus helenae Duncan, 1876, with A. helenae var. minor Duncan, 1876, have all been described from St Helena, Agelecyathus helenae and $A$. helenae var. minor as attached 'on an Ostrea'. The depth is not indicated, the substrate suggests shallow water. Unfortunately the type material of these taxa is lost. Duncan's descriptions and illustrations correspond to Polycyathus as conventionally understood in more recent
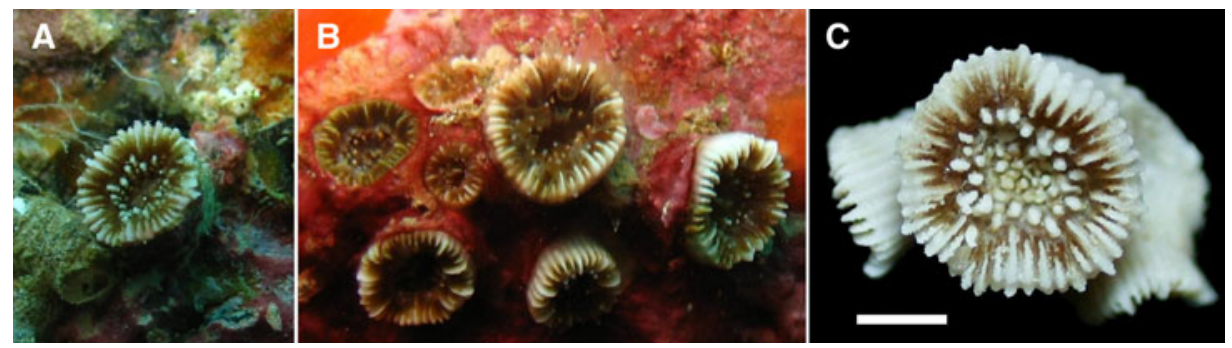

Fig. 6. Two live colonies of Polycyathus atlanticus (A, B) near One Hook, 10-15 m depth (photos P.W.); (C) skeleton cleaned of soft tissues, upper side of one calice RMNH 40169 (photo H.Z.). 
publications that provide detailed descriptions and illustrations, e.g. Zibrowius (1980) and Cairns (2000). Within a Polycyathus species, among specimens from the same habitat and even within a single colony, considerable variation may be found in the size of corallites, number of septa, proportions of pali, etc. This has particularly been shown in the case of Mediterranean Polycyathus (Zibrowius, 1980). Abundant material of Polcyathus is now available from St Helena (not to be detailed here), topotypic of Duncan's (1876) taxa. Considering the variability observed, Duncan's $P$. atlanticus and A. helenae (including var. minor) are considered to represent but one species, for which the first name, $P$. atlanticus has to be retained.

Zibrowius (1980) pointed out certain similarities between Polycyathus and Astrangia (conventionally placed in distant families, Caryophylliidae and Rhizangiidae) and the difficulty of placing one or the other species in either genus. If higher and more distinct pali-like rods (decreasing towards the centre) are characteristic of 'typical' Polycyathus and a gradient of lower septal dentation is characteristic of 'typical' Astrangia, reality often does not follow this clear-cut pattern. In colonies with larger, typical Polycyathus corallites in the centre, low, oblique, peripheral corallites may show a tendency towards Astrangia features. Further, in the case of some species described as Astrangia, one may argue that they would better fit Polycyathus.

At Ascension, Irving (1989) recorded Astrangia from 'underhangs and shallow caves', and later (Irving, 2013) referred to the same population ('underhangs, under boulders and shallow caves') as Astrangia solitaria. Analysis of photos of his 1985 specimens registered at USNM as Astrangia sp. results in some ambiguity: certain corallites are more typically Polycyathus, with higher distinct rod-like pali-structures whereas others have septal edges more simply denticulate. The small and few samples collected by P.W. in 2012 comprise 'typical-Polycyathus' corallites. Our impression is that all these samples from Ascension Island (R.I. and P.W.) can be referred to a single, variable species, $P$. atlanticus, the same that occurs at St Helena.

Some comments are needed in this context on Astrangia solitaria (Lesueur, 1817). The poor original description and illustration, based on material from Guadeloupe, Lesser Antilles, suggest that it could indeed be the species well presented under that name by Cairns (2000) as an apparently widespread tropical West Atlantic Astrangia: reptoid colonies with cylindrical corallites budded from narrow stolons. The specific name solitaria may seem in contradiction with the typical colonial nature of Astrangia species. However, it refers to the feature that organic connection between polyps is lost at an early stage and that the stolons between corallites are easily encrusted and concealed. We consider that $A$. solitaria - as described by Cairns (2000) - is not represented among the species from Ascension we had the opportunity to examine.

Several species of Polycyathus have been reported from tropical and temperate regions of the Atlantic (East and West, islands and archipelagos). Species distinction is problematic in these cases. Polycyathus atlanticus may also occur outside St Helena and Ascension, and as the oldest described species may have junior synonyms. A special, critical study of Atlantic Polycyathus should, of course, also take into account biological and DNA data.
Rhizosmilia gerdae Cairns, 1978

Family Caryophyllidae (but needs revision)

Rhizosmilia gerdae Cairns, 1978, pp. 219-222, pl. 1, figures 1-7; Cairns, 1979, pp. 142-143, pl. 27, figures 5-8; Cairns, 2000, p. 124.

Material (2012, P.W.): Boatswain Bird Island $\left(07^{\circ} 56.182^{\prime} \mathrm{S}\right.$ $\left.14^{\circ} 18.516^{\prime} \mathrm{W}\right), 1$ September 2012 , five dry specimens and four in ethanol (RMNH Coel. 40171). - Southeast Bay (07 $\left.{ }^{\circ} 57.266^{\prime} \mathrm{S} 14^{\circ} 18.476^{\prime} \mathrm{W}\right), 1$ September 2012 , five dry specimens (RMNH Coel. 40172). Older samples: Two samples from Ascension collected in November 1985 and donated by Robert Irving are registered as Rhizosmilia gerdae, USNM 78392 and USNM 78393. One of these (USNM 78392) was examined on the basis of photos. - A third sample, registered Rhizopsammia sp., USNM 1136486 (collecting date May 1981, collector?) was also examined on the basis of photos (belonging to the same species).

Habitat: Forming flat encrusting colonies to small lumps, usually consisting of several polyps (Figure $7 \mathrm{~A}, \mathrm{~B}$ ), on dark walls and in small caves in 3 to at least $15 \mathrm{~m}$ depth, fairly common; also below large boulders in at least 10-15 m depth. Irving (2013) recorded 'Rhizosmilia sp. cf. gerdae' from 'underhangs, under boulders and shallow caves', i.e. in similar habitats. The species was not illustrated but photos of samples deposited at USNM show that these indeed belong to the same species as the one collected by P.W. in 2012.

Morphology: Rather low subcircular corallites rising from a spreading common basal coenosteum on which they are well separated (Figure $7 \mathrm{~A}, \mathrm{~B}$ ). Sections at their base reveal concentric structures (Figure $7 \mathrm{D}$ ) such as described by Cairns from West Indian material (increase of diameter by adding exothecal dissepiments over raised costae). Generally 48 septa in four cycles, rarely some reduced $\mathrm{S}_{5}$ (Figure $7 \mathrm{C}$ ). Typically large paliform lobes in front of the penultimate septa. Columella a small cluster of narrow rods, much lower than the crown of paliform lobes.

All Ascension material is from shallow water where strong hydrodynamics prevail. Low, encrusting colonies appear normal in this environment. This stands in contrast to samples described by Cairns $(1978,1979,2000)$ from the American Atlantic, which were all from deeper water (exceeding $100 \mathrm{~m}$, even down to $300 \mathrm{~m}$ ), and were characterized as placoid clumps. Further, septa of the 5th cycle are more common there. Our identification of the Ascension 2012 specimens as belonging to this species is surely influenced by Cairns' corresponding identification of previous samples of the same Ascension origin (USNM). But - having in mind Mediterranean-NE Atlantic species of a wide ecological range and considerable morphological plasticity - we tend to agree with Cairns and to consider the sampled Ascension population a shallow-water morph of $R$. gerdae.

In order to better understand the extent of local intraspecific variation at Ascension, complementary collecting into deeper water would be welcome, as well as DNA data for comparing the remote insular population with West Indian populations. Investigation of the reproductive biology of this species would also be a rewarding subject.

According to Cairns $(1978,1979,2000)$ R. gerdae is widespread in the tropical American Atlantic, from the Yucatan Channel through the Antilles and Florida to the Bahamas. It is not (yet?) known from the other remote Central South Atlantic island, St Helena. 

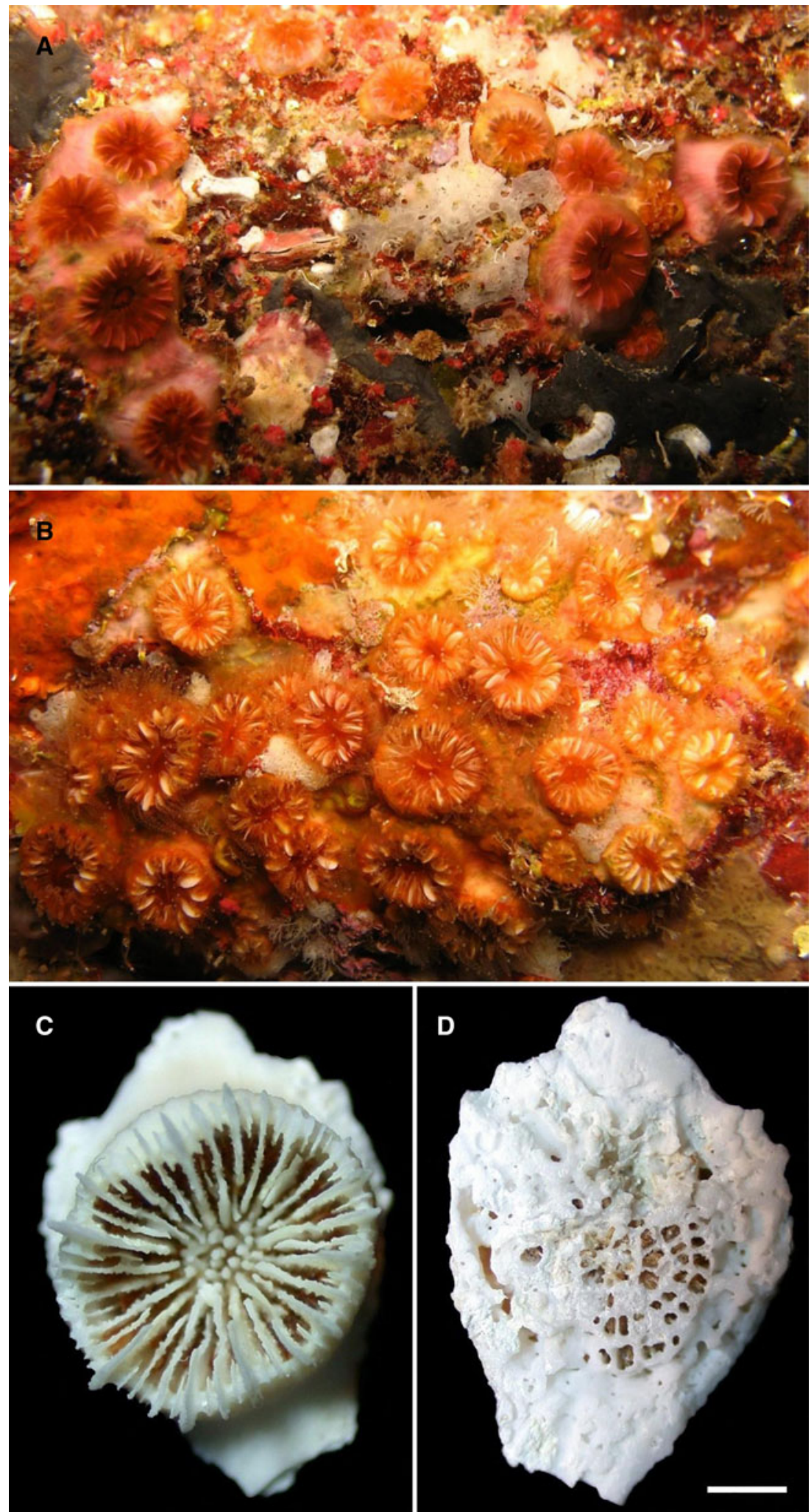

Fig. 7. Two live colonies of Rhizosmilia gerdae (A, B), both from Boatswain Bird Island, 10-15 m depth (photos P.W.). Corallite cleaned of soft tissues: (C) calice and (D) basal section showing concentric structure (photo H.Z.).

Siderastrea radians (Pallas, 1766)

Family Siderastreidae

Material (2012, P.W.): Near Porpoise Rock (07 ${ }^{\circ} 54.022^{\prime} \mathrm{S}$ $\left.14^{\circ} 20.964^{\prime} \mathrm{W}\right), 10 \mathrm{~m}$ depth, 31 August 2012, one dry specimen (RMNH Coel. 40159). - English Bay (07 $53.653^{\prime} \mathrm{S}$ $\left.14^{\circ} 22.950^{\prime} \mathrm{W}\right), 5 \mathrm{~m}$ depth, 4 September 2012 , one dry specimen (RMNH Coel. 40542). - Catherine Point, tide pools $\left(07^{\circ} 55.818^{\prime} \mathrm{S} 14^{\circ} 25.173^{\prime} \mathrm{W}\right), 2$ September 2012, seven fragments in ethanol (RMNH Coel 40163). - Mars Bay $\left(07^{\circ} 59.290^{\prime} \mathrm{S} 14^{\circ} 24.205^{\prime} \mathrm{W}\right), 3$ September 2012 , one specimen 


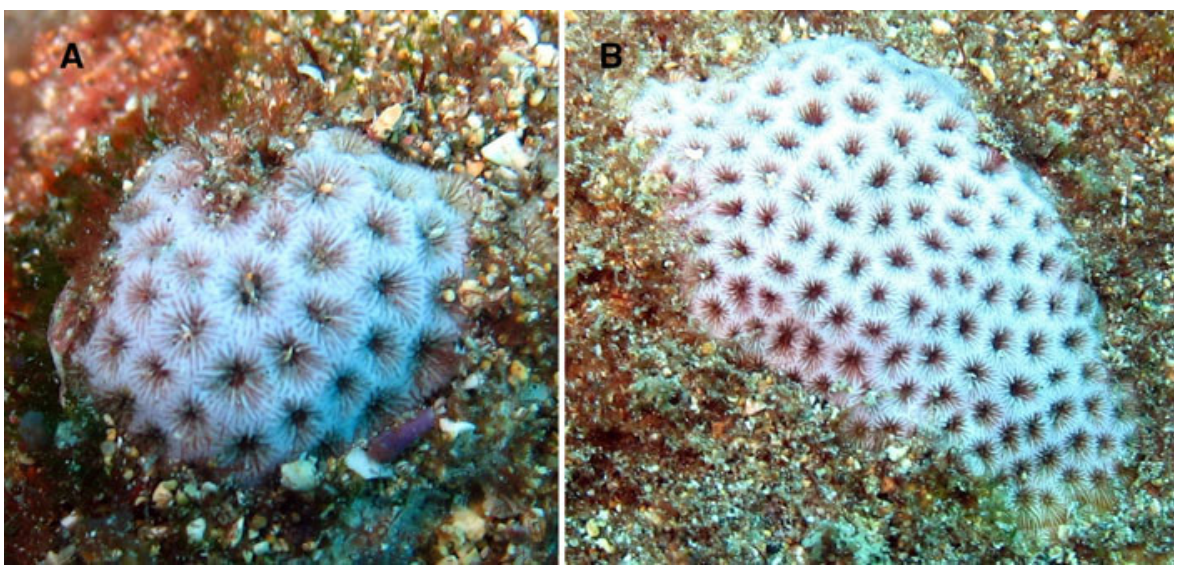

Fig. 8. Two live specimens of Siderastrea radians (A, B) near Porpoise Rock, 5-10 m depth (photos P.W.).

in ethanol (RMNH Coel. 40164). - Comfortless Cove $\left(07^{\circ} 54.614^{\prime} \mathrm{S} 14^{\circ} 24.212^{\prime} \mathrm{W}\right), 29$ August 2012, three specimens in ethanol (RMNH Coel. 40165). Older samples: Ascension, locality not specified, coll. Ascension diving club, one hemispheric colony (BMNH 1980.10.14.1). - Payne Point, shallow water pools, coll. Ascension diving club, x.10.1972, five encrusting colonies or fragments (BMNH 1980.10. 14.2-4). - Northeast Bay, tide pools on rocky point west of main beach, coll. R.B. Manning, 19.5.1971 (Asc 5), one colony (USNM). - Rocky Point, northern edge of English Bay, intertidal pools, subtidal rock shore, coll. R.B. Manning, 21.5.1971 (Asc 11), five colonies (USNM). Rocky Point, northern edge of English Bay, tide pool, coll. R.B. Manning, 22.5.1971 (Asc 15), four colonies, one of them with cryptochirid crypts (USNM). - Turtle Shell Beach, northern edge southwest Bay, tide pool, coll. R.B. Manning, 25.5.1971 (Asc 23), three colonies (USNM). - SW coast, Mars Bay, exposed rocky shore with tidal pools, coll. J.C. den Hartog, 31.5.1983 (stat. 1), one colony (RMNH Coel. 17343).

Habitat: forming light brown to grey crusts and small lumps down to at least $20 \mathrm{~m}$ depth (Figure 3).

Morphology: Colonies attached, small and predominantly encrusting (Figure 8 ). Calices $\sim 3 \mathrm{~mm}$ in maximum diameter, slightly polygonal in outline, resembling small pits with thick corallum walls around. A coenosteum is absent. The septa are thick and dense; they reach downward onto a small columella consisting of a cluster of densely packed small pillars. Siderastrea radians at Ascension does not form large colonies as in various other localities across the Atlantic, e.g. the Caribbean (Roos, 1971) and the Cape Verde Islands (Boekschoten \& Best, 1988). Owing to its small calice size, S. radians can be confused with $S$. stellata Verrill, 1901, which may show sharper corallum wall edges (Veron, 2000). The main difference between the two species is that S. stellata, a Brazilian endemic, has a fourth cycle of septa, which is lacking in S. radians (Menezes et al., 2013). A third Siderastrea species has been reported from the southern Atlantic, S. siderea (Ellis \& Solander, 1786) from Brazil, but this species has larger calices than $S$. radians (Neves et al., 2010).

One colony of $S$. radians in the USNM from Ascension Island shows typical lunuliform crypt apertures. Gall crabs had been extracted from this coral by H.Z., which were identified as Opecarcinus hypostegus (Shaw \& Hopkins, 1977) by
Kropp \& Manning (1987) without mentioning the host. So far three species of Atlantic gall crabs have been reported from Siderastrea, but their identity cannot always be confirmed (Van der Meij, 2014). The most likely cryptochirid that inhabited the empty pits in S. radians at Ascension is Kroppcarcinus siderastreicola Badaro, Neves, Castro \& Johnsson, 2012, a species that has also been found in Brazil and the Caribbean (Badaro et al., 2012; Van der Meij, 2014).

\section{Molecular data}

DNA was extracted from three specimens of Siderastrea radians, one specimens of Favia gravida and one specimen of Rhizosmilia gerdae. For all specimens, DNA extractions were highly fragmented and of low molecular weight, as is often observed for ethanol-preserved specimens (Gaither et al., 2011). As a result, the success of PCR amplification varied from specimen to specimen. For S. radians, amplification and sequencing was possible for all three genes. For $F$. gravida, amplification was only possible for COI, and all attempts at sequencing $R$. gerdae failed.

For $S$. radians, a 613 bp fragment sequenced for COI had $100 \%$ identity with $S$. radians and S. siderea on BLAST. A $649 \mathrm{bp}$ fragment was sequenced for $\beta$-tubulin, which had $98 \%$ identity with $S$. radians and $95 \%$ identity with $S$. siderea on BLAST. For Pax-C, a $217 \mathrm{bp}$ fragment was sequenced with $99 \%$ identity with $S$. radians and $96 \%$ identity with S. siderea on BLAST. For the two nuclear loci, sequence similarity with $S$. radians was greater than S. siderea, confirming the identification of the Ascension specimens as S. radians.

For F. gravida, a 637 bp fragment was sequenced for COI, which had $100 \%$ identity with Favia fragum and Colpophyllia natans. A COI sequence for $F$. gravida was not available in the BLAST database. Slow sequence evolution in the mitochondrial COI gene has been documented for anthozoans (Huang et al., 2008), and the lack of divergence between sister taxa such as $F$. gravida and $F$. fragum is not unexpected at this locus. Unfortunately, it was not possible to amplify and sequence the $\beta$-tubulin gene or Pax-C intron with the present material, due to low quality of the extracted DNA. These two loci are known to differentiate $F$. gravida from $F$. fragum (Nunes et al., 2011). Additional specimens from Ascension, preserved in more appropriate buffers, would be required for confirming the identification of F. gravida using molecular methods (Gaither et al., 2011). 


\section{DISCUSSIDN}

The results from the $\mathbf{2 0 1 2}$ field collection show that there are at least five scleractinian species present in the shallow waters of Ascension, three of which are zooxanthellate (Favia gravida, Madracis sp., Siderastrea radians) and two without zooxanthellae (Polycyathus atlanticus and Rhizosmilia gerdae). Madracis sp. and P. atlanticus are new records for the area. Ascension's shallow-water scleractinian fauna is remarkably poor. This is most probably related to its isolated position and to its young geological age (not more than $2 \times$ $10^{6}$ years -Ashmole \& Ashmole, 1997). None of its coral species are endemic whereas the fauna of much older St Helena Island, the other very isolated island of the tropical South Atlantic, includes two endemic species, Balanophyllia helenae Duncan, 1876, and Sclerhelia hirtella (Pallas, 1766), both of which can be found in shallow water by snorkelling (Den Hartog, 1989b).

Favia gravida and Siderastrea radians are both amphiAtlantic (Laborel, 1974; Hoeksema, 2012), the former occurring at both Ascension and St Helena Islands, the latter presently not known from St Helena Island. A genetic comparison of Ascension material with specimens from both sides of the Atlantic might be able to elucidate from where these species have colonized Ascension Island. Despite being brooders and having a relatively shorter larval dispersal phase when compared with broadcasters (Nunes et al., 2011), they were able to colonize these distant islands. Rafting could perhaps explain the presence of $F$. gravida and $S$. radians at these remote islands. This means of dispersal could be particularly relevant for species occurring in the intertidal zone (Hoeksema et al., 2012), but it should be kept in mind that in other climate phases of the Quaternary (and before) currents may have been different in position and intensity.

The presence of Rhizosmilia gerdae, previously only known from the Caribbean (Cairns, 200o) indicates a zoogeographic link with the tropical western Atlantic, a link also shown for several other groups, such as zoantharians (Reimer et al., 2014), hydrocorals (Hoeksema et al., 2017), fishes (Wirtz et al., 2017), and heterobranch sea slugs (Padula et al., 2014).

\section{ACKNOWLEDGEMENTS}

P.W. is grateful to Paul Brickle and the Shallow Marine Surveys Group for the invitation to take part in the August-September 2012 expedition to Ascension Island. The funding for this work came from a grant to Dr Paul Brickle from the Darwin Initiative (EIDCFo12). We are grateful to the Shallow Marine Surveys Group and the South Atlantic Environmental Research Institute for organizing the expedition. We are also very grateful to Ascension Island Government, the members of staff at the Conservation Centre and Ascension Island Dive Club for their cooperation, accommodation and hospitality. We are grateful to British Forces South Atlantic Islands for their logistic support. Thanks to Stedson Stroud and Jolene Sim of the Ascension Conservation Department for their help during the expedition. Work by F.L.D.N. was supported by a grant from the Regional Council of Brittany, from the European Funds (ERDF) and supported by the 'Laboratoire d'Excellence' LabexMER (ANR-10-LABX-19) and co-funded by a grant from the French government under the programme 'Investissements d'Avenir'. Stephen D. Cairns discussed Rhizosmilia gerdae with H.Z. and was helpful by sending photos of corals from Ascension deposited at USNM. Thanks also to Christopher Mah for comments on the identity of a starfish species and to Sancia van der Meij for her helpful remarks on the identity of gall crab species. Miranda Lowe (Natural History Museum, London) sent a historical specimen of $P$. ascensionis on loan to BWH. Finally, we are grateful to two anonymous reviewers for their comments.

\section{REFERENCES}

Amaral F.D. and Ramos C.A.C. (2007) Skeletal variability of the coral Favia gravida (Verrill, 1868) from Brazil. Biota Neotropica 7, 245-251.

Ashmole N.P. and Ashmole M.J. (1997) The land fauna of Ascension Island: new data from caves and lava flows, and a reconstruction of the prehistoric ecosystem. Journal of Biogeography 24, 549-589.

Badaro M.F.S., Neves E.G., Castro P. and Johnsson R. (2012) Description of a new genus of Cryptochiridae (Decapoda: Brachyura) associated with Siderastrea (Anthozoa: Scleractinia), with notes on feeding habits. Scientia Marina 76, 517-526.

Boekschoten G.J. and Best M.B. (1988) Fossil and recent shallow water corals from the Atlantic islands off Western Africa. Zoologische Mededelingen, Leiden 62, 99-112.

Cairns S.D. (1978) New genus and species of ahermatypic coral (Anthozoa: Scleractinia) from the western Atlantic. Proceedings of the Biological Society of Washington 91, 216-221.

Cairns S.D. (1979) The deep-water Scleractinia of the Caribbean and adjacent waters. Studies on the Fauna of Curaçao and Other Caribbean Islands 57, 1-341.

Cairns S.D. (2000) A revision of the shallow-water azooxanthellate Scleractinia of the western Atlantic. Studies on the Natural History of the Caribbean Region 75, 1-231.

Chace F.A. and Manning R.B. (1972) Two new caridean shrimps, one representing a new family, from marine pools on Ascension Island (Crustacea: Decapoda: Natantia). Smithsonian Contributions to Zoology 131, 1-18

Cunninghame J. (1699) A catalogue of shells etc. gathered at the island of Ascension, by Mr. Cunninghame chirurgeon, with what plants he there observed. Philosophical Transactions of the Royal Society 21, 295-300.

Den Hartog J.C. (1989a) Herinneringen aan een reis naar Sint-Helena (1). Dieren 6, 48-53.

Den Hartog J.C. (1989b) Herinneringen aan een reis naar Sint-Helena (3). Dieren 6, 114-120.

Diekmann O.E., Bak R.P.M., Stam W.T. and Olsen J.L. (2001) Molecular genetic evidence for probable reticulate speciation in the coral genus Madracis from a Caribbean fringing reef slope. Marine Biology 139, 221-233.

Duncan P.M. (1876) Notices of some deepsea and littoral corals from the Atlantic Ocean, Caribbean, Indian, New Zealand, Persian Gulf and Japanese \& c. seas. Proceedings of the Zoological Society of London $44,428-442$.

Frade P.R., Reyes-Nivia M.C., Faria J., Kaandorp J.A., Luttikhuizen P.C. and Bak R.P.M. (2010) Semi-permeable species boundaries in the coral genus Madracis: introgression in a brooding coral system. Molecular Phylogenetics and Evolution 57, $1072-1090$. 
Gaither M.R., Szabo Z., Crepeau M.W., Bird C.E. and Toonen R.J. (2011) Preservation of corals in salt-saturated DMSO buffer is superior to ethanol for PCR experiments. Coral Reefs 30, 329-333.

Gardiner J.S. (1913) The corals of the Scottish national Antarctic expedition. Transactions of the Royal Society of Edinburgh 49, 687689.

Hoeksema B.W. (2012) Extreme morphological plasticity enables a free mode of life in Favia gravida at Ascension Island (South Atlantic) Marine Biodiversity 42, 289-295.

Hoeksema B.W. (2013) Erratum to: Extreme morphological plasticity enables a free mode of life in Favia gravida at Ascension Island (South Atlantic). Marine Biodiversity 43, 173.

Hoeksema B.W., Nunes F.L.D., Lindner A. and Nunes de Souza J. (2017) Millepora alcicornis (Hydrozoa: Capitata) at Ascension Island: confirmed identity based on morphological and molecular analyses. Journal of the Marine Biological Association of the United Kingdom 97, 709-712.

Hoeksema B.W., Roos P.J. and Cadée G.C. (2012) Trans-Atlantic rafting by the brooding reef coral Favia fragum on man-made flotsam. Marine Ecology Progress Series 445, 209-218.

Hoeksema B.W. and Wirtz P. (2013) Over 130 years of survival by a small, isolated population of Favia gravida corals at Ascension Island (South Atlantic). Coral Reefs 32, 551.

Huang D., Meier R., Todd P.A. and Chou L.M. (2008) Slow mitochondrial COI sequence evolution at the base of the metazoan tree and its implications for DNA barcoding. Journal of Molecular Evolution 66, $167-174$.

Irving R.A. (1989) A preliminary investigation of the sublittoral habitats and communities of Ascension Island, South Atlantic. Progress in Underwater Science 13, 65-78.

Irving R.A. (2013) Ascension Island's hermatypic but non-reef building corals. In Sheppard C.R.C. (ed.) Coral reefs of the United Kingdom overseas territories, coral reefs of the world 4. Dordrecht: Springer pp. 213-221.

Kitahara M.V., Cairns S.D., Stolarski J., Blair D. and Miller D.J. (2010) A comprehensive phylogenetic analysis of the Scleractinia (Cnidaria Anthozoa) based on mitochondrial CO1 sequence data. PLoS ONE 5, e11490

Kropp R.K. and Manning R.B. (1987) The Atlantic gall crabs, family Cryptochiridae (Crustacea: Decapoda: Brachyura). Smithsonian Contributions to Zoology 462, 1-21.

Laborel J. (1971) Campagnes de la Calypso au large des côtes Atlantiques de l'Amérique du Sud (1961-1962), 25. Madréporaires et hydrocoralliaires récifaux des côtes brésiliennes. Systématique, écologie, répartition verticale et géographique. Annales de l'Institut Océanographique, Paris 47, 171-229.

Laborel J. (1974) West African reef corals: a hypothesis on their origin. Proceedings 2nd International Coral Reef Symposium 1, 425-442.

Lesueur C.A. (1817) Observations on several species of the genus Actinia; illustrated by figures. Journal of the Academy of Natural Sciences of Philadelphia 1, 149-154, 169-189, pls 7-8.

Lesueur C.A. (1821) Description de plusieurs animaux appartenant aux Polypiers Lamellifères de M. le Chev. de Lamarck. Mémoires du Muséum National d'Histoire Naturelle 6, 271-299, pls 15-17.

Lubbock R. (1980) The shore fishes of Ascension Island. Journal of Fish Biology 17, 283-303.

Lyman T. (1859) On a new species of (Astraea decactis). Proceedings of the Boston Society of Natural History 6, 260-263.
Manning R.B. and Chace F.A. (1990) Decapod and stomatopod Crustacea from Ascension Island, South Atlantic Ocean. Smithsonian Contributions to Zoology 503, 1-91.

Matthai G. (1928) A monograph of the Recent meandroid Astraeidae. Catalogue of the Madreporarian Corals in the British Museum (Natural History) 7, 1-288, pls 1-72.

Menezes N.M., Neves E.G., Barros F., Kikuchi R.K.P. and Johnsson R. (2013) Intracolonial variation in Siderastrea de Blainville (Anthozoa, Scleractinia): taxonomy under challenging morphological constraints. Biota Neotropica 13, 108-116.

Moseley H.N. (1881) Report on certain hydroid, alcyonarian, and madreporarian corals procured during the voyage of H.M.S. Challenger, in the years 1873-1876. Report on the Scientific Results of the Voyage of H.M.S. Challenger during the years 1873-76, Zoology 2, 1-248, pls 1-32.

Neves E., da Silveira F.L., Pichon M. and Johnsson R. (2010) Cnidaria, Scleractinia, Siderastreidae, Siderastrea siderea (Ellis and Solander, 1786): Hartt expedition and the first record of a Caribbean siderastreid in tropical Southwestern Atlantic. Checklist 6, 505-510.

NMiTA (2013) Neogene Marine Biota of Tropical America. Madrasis decactis. http://nmita.iowa.uiowa.edu/nmita/speciesDetails.page? genusNmFrmSpPg=Madracis\&subgenusName $=$ Madracis\&taxonName $=$ Zooxanthellate\%20Coral\&familyName=Pocilloporidae\&speciesName= decactis\&genstat $=3$ \&epithetName=Madracis (accessed http://nmita . iowa.uiowa.edu/database/corals/coralmnu.htm, 23 September 2013).

Nunes F., Fukami H., Vollmer S.V., Norris R.D. and Knowlton N. (2008) Re-evaluation of the systematics of the endemic corals of Brazil by molecular data. Coral Reefs 27, 423-432.

Nunes F.L.D., Norris R.D. and Knowlton N. (2011) Long distance dispersal and connectivity in amphi-Atlantic corals at regional and basin scales. PLoS One 6, e22298.

Padula V., Wirtz P. and Schrödl M. (2014) Heterobranch sea slugs (Mollusca: Gastropoda) from Ascension Island (South Atlantic). Journal of the Marine Biological Association of the United Kingdom. doi: $10.1017 /$ Soo25315414000575.

Pawson D.L. (1978) The echinoderm fauna of Ascension Island, South Atlantic Ocean. Smithsonian Contributions to the Marine Sciences 2, $1-31$.

Price H. and John D.M. (1980) Ascension Island, south Atlantic: a survey of inshore benthic macroorganisms, communities and interactions. Aquatic Botany 9, 251-278.

Reimer J.D., Lorion J., Irei Y., Hoeksema B.W. and Wirtz P. (2014) Ascension Island shallow-water zoanthids (Zoantharia: Hexacorallia: Cnidaria) and their zooxanthellae (Symbiodinium). Journal of the Marine Biological Association of the United Kingdom. doi: 10.1017/ Soo25315414000654.

Ridley S.O. (1881) Madreporaria. In Report on a collection made by Mr. T. Conry in Ascension Island. The Annals and Magazine of Natural History (Ser 5) 8, 438-440.

Roos P.J. (1971) The shallow-water corals of the Netherlands Antilles. Studies on the Fauna of Curaçao and other Caribbean Islands 37, 1108 , pls $1-53$.

Rosewater J. (1975) An annotated list of the marine mollusks of Ascension Island, South Atlantic Ocean. Smithsonian Contributions to Zoology 189, 1-41.

Shaw J.K. and Hopkins T.S. (1977) The distribution of the family Hapalocarcinidae (Decapoda, Brachyura) on the Florida Middle Ground with a description of Pseudocryptochirus hypostegus new species. Proceedings 3 rd International Coral Reef Symposium, Miami $1,177-183$. 
Stock J.H. and Vonk R. (1989) Biological groundwater studies in Ascension Island (South Atlantic) October-November 1989. Verslagen en Technische Gegevens Instituut voor Taxonomische Zoölogie (Zoölogisch Museum) Universiteit van Amsterdam, 56, 1-10.

Studer T. (1889) Die Forschungsreise S.M.S. Gazelle in den Jahren 1874 bis 1876. 3. Zoologie und Geologie. Berlin: E.S. Mitterer \& Sohn.

Van der Meij S.E.T. (2014) Host species, range extensions, and an observation of the mating system of Atlantic shallow-water gall crabs (Cryptochiridae). Bulletin of Marine Science 90, 1001-1010.

Veron J.E.N. (2000) Corals of the world. Volumes 1-3. Townsville: Australian Institute of Marine Science.

Verrill A.E. (1868) Notes on Radiata in the Museum of Yale College, with descriptions of new genera and species. No. 4. Notice of the corals and echinoderms collected by Prof. C.F. Hartt, at the Abrolhos Reefs, Province of Bahia, Brazil, 1867. Transactions of the Connecticut Academy of Arts and Science 1, 351-371.

Verrill A.E. (1901) Variations and nomenclature of Bermudian, West Indian and Brazilian reef corals, with notes on various Indo-Pacific corals. Transactions of the Connecticut Academy of Arts and Sciences 11, 63-168, pls 10-35.
Werner T.B. (1997) Recent zooxanthellate corals (Order: Scleractinia) from Ascension and St. Helena Islands, South Atlantic, with a summary of their geographic distribution in the Atlantic Ocean. MS thesis. University of Maryland, College Park, MD.

Wirtz P., Bingeman J., Bingeman J., Fricke R., Hook T.J. and Young J. (2017) The fishes of Ascension Island, central Atlantic Ocean - new records and an annotated check-list. Journal of the Marine Biological Association of the United Kingdom 97, 783-798.

Zibrowius H. (1980) Les Scléractiniares de la Méditerranée et de l'Atlantique nord-oriental. Mémoires de l'Institut Océanographique, Monaco 11, 1-284, pls 1-107.

and

Zlatarski V.N. and Estalella N.M. (1982) Les scléractiniaires de Cuba avec des données sur les organismes associés. Sofia: Académie Bulgare des Sciences.

\section{Correspondence should be addressed to:}

P. Wirtz

Centro de Ciências do Mar, Universidade do Algarve, P-8000-117 Faro, Portugal email: peterwirtz2004@yahoo.com 